\title{
Corruption and its diverse effect on credit risk: global evidence
}

\author{
Rashedul Hasan ${ }^{1 *}$ [D and Muhammad Ashfaq ${ }^{2}$
}

\begin{abstract}
Corruption has a complex relationship with economic growth. We have explored the impact of corruption on credit risk from a global perspective. The sample consists of 178 countries and covers 18 years that range from 2000 to 2017. Non-performing loan (NPL) is used as a proxy for credit risk and data regarding NPL is collected from the World Bank Database. Corruption scores are collected from the Transparency International reports. Panel regression results provide a positive association between corruption and credit risk for the global sample. Generalized Methods of Moments regression and robustness tests validate the findings. However, sub-sample analysis provides support for "grease the wheel" hypothesis for high corruption countries and indicates that corruption is beneficial in a weak form of governance and excessive regulatory pressure. This study advocate for the importance of strong governance mechanisms in high corruption countries that can minimize the impact of corruption on banking sector profitability and ensure economic development. Unlike past literature, we provide global evidence on the association between corruption and credit risk for the banking sector which allows generalizability.
\end{abstract}

Keywords: Corruption, Credit risk, Banks, Bureaucracy, Corporate finance and governance

JEL Classifications: D73, G21

\section{Introduction}

Corruption has been an important issue for social scientists as it causes social and economic problems in the society. The government makes laws to curtail corruption and these law-making procedure and implementation resulted in accounting cost. Such an effort requires fruitful results in the form of socioeconomic profit. Transparency International [46] defines corruption as "the abuse of entrusted power for private gain". Corruption can be classified into two categories. One is "petty corruption" that is referred to the low and mid-level public to abuse their power and another is "grand corruption" that is referred to the institution. These institutions could be private or government institutions. Khalil et al. [33] categories corruption into two broad categories of "bribery

\footnotetext{
*Correspondence: hasanaiub05@gmail.com

${ }^{1}$ School of Economics, Finance and Accounting, Coventry University,

Priory St, CV1 5FB Coventry, Warwickshire, UK

Full list of author information is available at the end of the article
}

and extortion". The bribery is considered to play its role by cooperation, while extortion is benefiting one party to the detriment of another. In net, extortion is a zerosum game, while in bribery total is more than the sum of individuals, which means both participants gain and their total utility increases. Corruption plays its part in allowing beneficial transactions, in the form of bribery, which could have a diverse impact on economic growth [44]. It misallocates the reward among the stakeholders, and some stakeholders gain more, who deserve less, than the others, who deserve the more. Corruption is one of the obstacles in developing countries that hinder the pace of improving the life quality of citizens [45].

There are two schools of that perceive corruption to serve as a "grease or sand" for economic development. While Mauro [36] began the debate by producing a negative association between corruption and economic development, such a relationship has been confirmed by the latest studies [44]. However, empirical evidence on the positive association between corruption and economic 
development has also emerged. For example, Huang [30] find a significant positive impact of corruption on economic development in the Asia-Pacific region. Corruption and economic development studies have evolved and recent studies have shifted toward exploring the impact of corruption on financial development. Financial development has proven to be a decisive factor in economic development [44]. Bolarinwa and Soetan [12] provide mixed findings on the impact of corruption on bank profitability for emerging markets while confirming a positive impact on the developed countries.

A well-defined and efficient financial system enables the economy to gain maximum utility for its stakeholders. In terms of financial economics, the resources move from the market where marginal reward or utility is relatively less to the market where marginal reward or utility is more. So, the financial system aims to circulate the financial resources in an efficient and frictionless manner. An important feature of the financial institution especially the banking sector is the issuance of the loan. Bank loan serves as a major source of firm financing. However, banks could suffer from a higher degree of agency problem in the presence of corruption, which could increase bad loans [2]. Thus, corruption creates a toxic environment in the banking sector that allows the loan officer to extract private benefits from loan contracts at the expense of the stakeholders (more specifically the depositors). Uddin et al. [47] exerts the importance of the absence of corruption for long -term stability of the financial sectors and provides empirical evidence that control of corruption reduces bank risk-taking behaviors and improves stability.

The bank lending corruption has been explored by the degree of non-performing loan (NPL) in recent studies (please see Bahoo [6]). A non-performing loan is the amount of money upon which debtor cannot pay interest according to schedule. The nonpayment amount would be interested payment, principal amount or both. Generally, the delay in scheduled payment more than 90 days is considered as a non-performing loan. The reason for a non-performing loan may be different. Some may be systematic i.e. related to the overall economy and some may be firm-specific. Nepotism, political influence and bribery are some important causes of issuing non-performing loan by banks. Developing countries, where financial institutions are not well developed and the rate of bribery is high, usually, face such problems in large extent. Abuzayed et al. [1] find that corruption increase bank lending but reduces its profit potential for both developed and developing countries. Bank operating in highly corrupt environment engage in income smoothing exercise to smooth their positive earnings [41]. Such findings require further exploration of the association between corruption and credit risk for the banking sector.
Therefore, we aim to provide global evidence on the impact of corruption on bank credit risk. This paper is divided into five sections. The "Introduction" section provides the rationale of the study by outlining the research problem. In the "Literature review and hypothesis development" section, we have focused on the extensive review of the literature to identify gaps in the existing literature in the context of corruption and credit risk of the banking sector. Review of the past literature provides an opportunity for this study to develop a hypothesis. The "Methodology" section of the paper deals with data description and empirical model for statistical analysis. Results obtained through the analysis of empirical models are discussed in the "Results and discussion" section. Finally, we provide a conclusion, policy recommendation and suggestions for future research in "Conclusion" section.

\section{Literature review and hypothesis development}

Corruption has been an important grey area for social scientists, especially in the aspect of politics and economics [53]. It is very technical to define corruption as the definition of corruption may vary from space to space and time to time. Some countries may define an act as a crime, while another could consider it an ethical problem or rent-seeking, and someone may consider it a part of game theory. So different studies analyze it in a different aspect and conclude different results under the typical definition. Tabish and Jha [45] analyze the relationship between corruption-free indicators, standard procedures and fair punishment. The study concludes that fair punishment resulted in a decrease in corruption. Justice without discretion is one of the influential elements that cause a decrease in corruption in a society. Ethical values play a vital role to keep an individual aloof from corruption.

Different sectors have a different propensity of corruption. Mauro [37, 38] argues that there is more corruption in public investment sector like infrastructure and capital-intensive investment than health and education sector. The infrastructure sector and military expenditure have more rent-seeking element than the health and education sector. So, the structure of financial institutions especially the banking sector is important in analyzing the misallocation of NPL and the relationship of the administrative structure of these institutions with corruption. Bougatef [14] analyzes the soundness of Islamic banks and concludes that there is a significant relationship between corruption and NPL. Financial sector of the economy makes it sure that financial resources are flowing efficiently in the financial system and the local and foreign investors are satisfied from financial institutions. The corruption in financial institutions shake 
the confidence level of the foreign investor and this has disaster impact especially on the developing economies as the non-performing loan would become a major element of gambling. Several factors lead to the growth or decline of the nonperforming loans, such as macroeconomic variables and bank-specific variables, banks ownership structure, corruption and information sharing. Among them, one of the main factors that affect the nonperforming loans is corruption. In developing countries, corruption plays a very important role in the growth of non-performing loans. Damanhur et al. [19] analyze the effect of micro and macro variables on non-performing financing by using panel data approach for 13 banks, consisting of 2014-2015 semiannual data. The results show the inflation and gross domestic product greatly affect non-performing financing indirectly. These macro variables change the prevailing sentiments in the market, and this ultimately changes the associated risk factors of NPL and in the result of this risk factor banks change the ratio of NPL accordingly.

Macro variables also have an impact on NPL. Umar [48] analyzes the Chinese banks and concludes that macro variables have a significant impact on the NPL of banks in case of China. Moral hazard has been an important topic in social economics. Corruption affects the performance of banks as banks misallocate the loan due to nepotism. Bougatef [15] concludes that there is a positive relationship between corruption and NPL. USA banks play an important role in the world economy, as these banks and stock markets are the major influential actors of the international financial system. Ghosh [28] shows that distressed banks having high NPL are major obstacles to obtain a sound financial system in the USA. These banks are a major cause to shake the confidence level of bank customers and in result, these banks become defaulter in recession.

Government structure plays a vital role to determine the level of corruption and non-performing loan. Fan et al. [25] studies the China financial system and conclude that government officers and bureaucrats are major actors for an excess portion of the non-performing loan in the financial banking system, as China is a communist country where most of the institutions are under the control of the state. Geletta [26] concludes that weak government institutions and weak credit policy assessment are the major cause of non-performing loan in Ethiopia. The similar conclusion is by Richard [43] who analyzes that weak analyses of credit policy and misallocation of resources are the major cause of non-performing loans. This could be analyzed in the aspect of moral hazard as moral hazard cause misallocation of resources. Dass et al. [20] provide evidence that public corruption in the USA results in lower firm value and increased information asymmetry. Brown et al. [17] further validated the negative impact of corruption on firm value.

Atkins et al. [5] use loan loss provision and analyze the relationship of corruption to non-performing loan and concludes that there is a positive relationship between corruption and loan loss provision. It means that earlier the bank recollects its debt, the lesser is the portion of the non-performing loan in bank financial statement. The other conclusion is that the deposit insurance scheme and government ownership in the banking system also affect the portion of the nonperforming loan. These insurance schemes and ownership of government increase the portion of the non-performing loan in the system and this corruption ultimately leads to inefficient allocation of financial resources.

Barth et al. [7] analyze the impact of information flow among financial institutions and finds that information sharing among financial institutions and banking system decrease the portion of non-performing loan. Boudriga et al. [13] concluded that an effective way to reduce the non-performing loan portion in the bank statement. The above literature study encompasses the NPL and corruption relationship by using a panel data approach. No study uses the corruption perception index, NPL and interest rate or interest rate spread simultaneously to analyze the relationship. The incorporation of interest rate spread would give a better result, as interest rate spread is the major element in determining the NPL.

$H_{1}$ Ceteris Paribus, Countries with a high level of corruption have a higher level of credit risk.

\section{Methodology \\ Data}

The study uses the corruption and credit risk (non-performing loan is used as a proxy) data of 178 countries across various regions, extracted from the World Bank database. The data ranges from the year 2000 to 2017, i.e. 18 years. Following Umar and Sun [48], we have selected the period due to the positive relationship between the non-performing loan and GDP growth. Unlike Umar and Sun [48], our study focused on country-level data and reports on the most recent available data. In a similar study, Bougatef [16] only reports findings based on a sample of 22 countries over the period 2008-2012. Out study thus overcomes the limitations of past studies with a superior sample and contributes to the generalizability of past findings exploring an association between corruption and credit risk. Data regarding macroeconomic variables are collected from the World Bank database, International Monetary Fund (IMF) Database and reports published by Transparency International. The 
data source for each variable is further highlighted in Table 4.

\section{Variable definition and model development}

Bank non-performing loans (NPL) to total gross loans are the dependent variable of the study. We have used the ratio to analyze the impact of corruption of the soundness of the banking system in the world. A higher value of the ratio means higher credit risk, and vice versa. Table 1 provides the NPL statistics by region over the period of 18 years spanning from 2000 to 2017 along with the average NPL score by region and year. The NPL data was collected from the World Bank database. We witness a decreasing trend in global NPL (from 14.02 to 3.44) until 2008. However, global NPL has increased since the global financial crisis in 2008.

Among the seven economic regions presented in Table 1, Europe has the highest NPL ratio followed by South Asia and sub-Saharan Africa. North American region has the lowest NPL ratio. More specifically, we find that the NPL score varies between various Asian regions. NPL score is higher in South Asia as compared to East Asia. Islam and Nishiyama [31] conclude that South Asian countries (the study explore Bangladesh, India, Nepal and Pakistan) suffer from credit risk due to poor governance which results in moral hazard problems. Zha et al. [51] exert a strong credit risk interdependence among East Asian countries. However, we find limited comparative evidence on credit risk between South and East Asian countries which constitutes a major gap in the credit risk literature. Europe and Central Asia have shown significant improvement in credit risk management by reducing the NPL ratio from 21.22 in 2000 to 8.76 , a $58.72 \%$ decrease in 18 years. While we see a slight increase on NPL in Europe since 2013, the score has been decreasing since the publication of the credit risk management guidelines by the Basel Committee in 2015. This variation of NPL across regions has made the determinants of NPL an interesting topic of research [48]. Dimitrios et al. [21] confirm that country-specific factors contribute to the increase in NPL.

We have used Corruption as an explanatory variable in this study. Corruption Perception Index (CPI) published by Transparency International is used as a measure of corruption level for the sample. CPI scores for 2017 are provided in Table 2. Somalia has ranked 1 with a CPI score of

Table 1 Non-performing loan statistics

\begin{tabular}{|c|c|c|c|c|c|c|c|c|}
\hline \multirow[t]{2}{*}{ Year } & \multicolumn{8}{|l|}{ Region } \\
\hline & $\begin{array}{l}\text { East Asia and } \\
\text { Pacific }\end{array}$ & Europe & $\begin{array}{l}\text { Latin America and } \\
\text { Caribbean }\end{array}$ & $\begin{array}{l}\text { The Middle East and } \\
\text { North Africa }\end{array}$ & North America & South Asia & $\begin{array}{l}\text { Sub-Saharan } \\
\text { Africa }\end{array}$ & $\begin{array}{l}\text { Average } \\
\text { NPL by } \\
\text { year }\end{array}$ \\
\hline 2000 & 6.83 & 21.22 & - & - & - & - & - & 14.02 \\
\hline 2001 & 8.00 & 17.91 & 1.62 & - & - & - & - & 9.18 \\
\hline 2002 & 6.59 & 11.02 & 6.35 & - & - & - & - & 7.57 \\
\hline 2003 & 4.66 & 8.39 & 5.57 & - & - & - & - & 6.05 \\
\hline 2004 & 4.23 & 6.07 & 4.20 & - & - & - & - & 4.67 \\
\hline 2005 & 5.24 & 9.25 & 3.66 & 8.21 & 0.50 & 8.98 & 7.35 & 6.07 \\
\hline 2006 & 5.04 & 7.32 & 2.79 & 6.47 & 0.40 & 7.30 & 9.91 & 5.41 \\
\hline 2007 & 4.87 & 5.36 & 2.42 & 5.31 & 0.40 & 7.44 & 7.29 & 4.45 \\
\hline 2008 & 2.52 & 3.25 & 2.68 & 6.59 & 0.80 & 5.79 & 6.98 & 3.44 \\
\hline 2009 & 3.23 & 6.94 & 3.51 & 7.70 & 3.13 & 9.49 & 9.84 & 5.89 \\
\hline 2010 & 2.87 & 7.68 & 2.95 & 7.33 & 2.79 & 18.06 & 8.21 & 6.26 \\
\hline 2011 & 2.57 & 8.57 & 2.67 & 5.68 & 2.31 & 6.19 & 6.65 & 5.65 \\
\hline 2012 & 3.11 & 9.34 & 2.57 & 6.30 & 1.98 & 8.93 & 6.91 & 6.13 \\
\hline 2013 & 3.20 & 10.54 & 2.36 & 6.58 & 1.51 & 8.66 & 8.57 & 6.71 \\
\hline 2014 & 2.76 & 10.48 & 2.35 & 6.55 & 1.18 & 8.89 & 8.48 & 6.63 \\
\hline 2015 & 2.60 & 10.30 & 2.38 & 6.45 & 0.99 & 8.80 & 9.14 & 6.72 \\
\hline 2016 & 2.75 & 9.31 & 2.49 & 6.82 & 0.96 & 7.49 & 10.62 & 6.71 \\
\hline 2017 & 2.86 & 8.76 & 2.74 & 6.74 & 0.79 & 7.67 & 11.31 & 6.69 \\
\hline $\begin{array}{l}\text { Average NPL } \\
\text { by region }\end{array}$ & 4.11 & 9.53 & 3.14 & 6.67 & 1.36 & 8.74 & 8.55 & 6.57 \\
\hline
\end{tabular}

Bank nonperforming loans to total gross loans are the value of nonperforming loans divided by the total value of the loan portfolio (including nonperforming loans before the deduction of specific loan-loss provisions). The loan amount recorded as nonperforming should be the gross value of the loan as recorded on the balance sheet, not just the overdue amount 
Table 2 Corruption score of selected countries

\begin{tabular}{|c|c|c|}
\hline Country & CPI Score 2017 & Rank \\
\hline \multicolumn{3}{|c|}{ Low level of corruption } \\
\hline New Zealand & 89 & 180 \\
\hline Denmark & 88 & 179 \\
\hline Finland & 85 & 176 \\
\hline Norway & 85 & 176 \\
\hline Switzerland & 85 & 176 \\
\hline Singapore & 84 & 174 \\
\hline Sweden & 84 & 174 \\
\hline Canada & 82 & 170 \\
\hline Luxembourg & 82 & 170 \\
\hline Netherlands & 82 & 170 \\
\hline United Kingdom & 82 & 170 \\
\hline Germany & 81 & 169 \\
\hline Australia & 77 & 166 \\
\hline Hong Kong & 77 & 166 \\
\hline Iceland & 77 & 166 \\
\hline \multicolumn{3}{|c|}{ High level of corruption } \\
\hline Eritrea & 20 & 15 \\
\hline Angola & 19 & 13 \\
\hline Turkmenistan & 19 & 13 \\
\hline Iraq & 18 & 11 \\
\hline Venezuela & 18 & 11 \\
\hline Korea, North & 17 & 7 \\
\hline Equatorial Guinea & 17 & 7 \\
\hline Guinea Bissau & 17 & 7 \\
\hline Libya & 17 & 7 \\
\hline Sudan & 16 & 5 \\
\hline Yemen & 16 & 5 \\
\hline Afghanistan & 15 & 4 \\
\hline Syria & 14 & 3 \\
\hline South Sudan & 12 & 2 \\
\hline Somalia & 9 & 1 \\
\hline
\end{tabular}

9. A low score in the CPI index indicates that citizens of the country are not satisfied by the measures taken by the government to tackle corruption in the country and vice versa. Until 2011, CPI scores ranged from 0 (highly corrupt) to 10 (very clean). However, the scale has been revised and since 2012 the CPI scores range from 0 (highly corrupt) to 100 (very clean). Therefore, we have adjusted while calculating CPI scores following [42]. We define the corruption index (CI) as follows:

$$
\begin{aligned}
& C I=10-C P I \text { for the period } 2000-2011 \text { and } \\
& C I=10-\frac{C P I}{10} \text { for the period } 2012-2017
\end{aligned}
$$

This revised measure allows us to incorporate a higher level of corruption with high CI score. Table 3 provides a mean CI score of 6.36 , which indicates that corruption represents a serious concern for the majority of the countries. The average CI score ranges from a low 2.003 (North America) to high 7.547 (Sub-Saharan Africa). While a small number of past studies have explored the impact of corruption on credit risk [13, 42], a straightforward relation between corruption and credit risk has yet to be established.

Despite the difference $[16,42]$ in the findings of past studies, we emphasize the findings of Boudriga et al. [13] that a better corruption control can play a greater role in reducing NPL. NPL can distort the allocation of funds through the banking sector which is more likely to happen in a highly corrupt country [15]. Table 5 reports a negative correlation between corruption and credit risk which is further investigated with panel regression analysis.

Past studies on NPL literature have emphasized the importance of macroeconomic factors. Economic development is reported as a significant negative determinant of NPL by Ali and Daly [3] and was later confirmed by Park [42]. The correlation matrix provided in Table 5 indicates a negative link between corruption and economic growth (measured by GDP Growth) which highlights the fact that corruption serves as a great obstacle for the economic development of a country. Unemployment is associated with NPL by Bougatef [15] as an unemployed person become unable to repay debts which increase the non-performing loans. An increase in the capital-to-asset ratio can reduce risktaking behavior in the banking sector [52]. Bougatef [15] emphasizes on the importance of capital information disclosure quality that can be utilized by public and private credit registries to reduce credit risk.

Following the findings of Ghosh [27], we have included inflation as control as inflation increase the nominal interest rates and increase the chances of a default. Excessive deficit spending leads to the sovereign debt crisis, which may end up in banking sector turmoil [48]. Trade openness decreases corruption and thus, has the capabilities of reducing credit risk [24]. Remittances can provide alternative income streams to meet financial obligations and hence have a negative impact on NPL [34].

Therefore, we have included capitalization, credit disclosure, economic growth, inflation, public debt, remittance, trade openness and unemployment as control variables in this study. We attempt to investigate the causal link between corruption and credit risk using the following model that uses balanced panel data with 3204 observations: 
Table $3 \mathrm{Cl}$ scores across regions

\begin{tabular}{|c|c|c|c|c|c|c|c|}
\hline \multirow[t]{2}{*}{ Year } & \multicolumn{7}{|l|}{ Region } \\
\hline & $\begin{array}{l}\text { East Asia and } \\
\text { Pacific }\end{array}$ & $\begin{array}{l}\text { Europe and } \\
\text { Central Asia }\end{array}$ & $\begin{array}{l}\text { Latin America and } \\
\text { Caribbean }\end{array}$ & $\begin{array}{l}\text { The Middle East and } \\
\text { North Africa }\end{array}$ & North America & South Asia & $\begin{array}{l}\text { Sub- } \\
\text { Saharan } \\
\text { Africa }\end{array}$ \\
\hline 2000 & 7.136 & 5.718 & 8.227 & 8.790 & 1.500 & 8.400 & 8.883 \\
\hline 2001 & 7.027 & 5.827 & 7.767 & 8.930 & 1.750 & 9.325 & 8.994 \\
\hline 2002 & 7.014 & 5.635 & 7.587 & 8.815 & 1.650 & 8.725 & 8.798 \\
\hline 2003 & 6.845 & 5.192 & 7.490 & 6.250 & 1.900 & 8.750 & 8.551 \\
\hline 2004 & 6.655 & 5.137 & 7.103 & 6.010 & 2.000 & 8.413 & 8.119 \\
\hline 2005 & 6.341 & 5.014 & 7.057 & 5.900 & 2.000 & 8.138 & 7.743 \\
\hline 2006 & 6.250 & 4.996 & 6.853 & 6.020 & 2.100 & 7.613 & 7.611 \\
\hline 2007 & 6.077 & 4.902 & 6.307 & 6.170 & 2.050 & 7.038 & 7.255 \\
\hline 2008 & 6.086 & 4.924 & 6.357 & 6.075 & 2.000 & 7.075 & 7.264 \\
\hline 2009 & 5.818 & 4.941 & 6.370 & 6.115 & 1.900 & 7.200 & 7.240 \\
\hline 2010 & 5.773 & 4.933 & 6.253 & 6.010 & 2.000 & 7.150 & 7.221 \\
\hline 2011 & 5.700 & 4.946 & 6.224 & 6.079 & 2.096 & 7.067 & 7.149 \\
\hline 2012 & 5.882 & 4.727 & 5.870 & 5.935 & 2.150 & 7.163 & 6.753 \\
\hline 2013 & 5.845 & 4.720 & 5.933 & 6.080 & 2.300 & 7.125 & 6.811 \\
\hline 2014 & 6.109 & 4.647 & 5.873 & 5.985 & 2.250 & 7.050 & 6.819 \\
\hline 2015 & 6.118 & 4.571 & 7.037 & 5.925 & 2.050 & 7.088 & 6.843 \\
\hline 2016 & 5.564 & 4.582 & 5.817 & 6.200 & 2.200 & 6.513 & 6.981 \\
\hline 2017 & 5.323 & 4.580 & 5.810 & 6.155 & 2.150 & 6.450 & 6.813 \\
\hline Grand Total & 6.198 & 4.999 & 6.663 & 6.525 & 2.003 & 7.571 & 7.547 \\
\hline
\end{tabular}

$$
\text { Credit Risk }_{i t}=\beta_{0}+\beta_{1} \text { Corruption }_{i t}+\sum_{i=1}^{i} \beta_{2} \text { Controls }_{i t}+\varepsilon_{i t}
$$

where $i$ and $t$ subscripts indicate country and year, respectively. Credit risk is measured with non-performing loans which are regressed with corruption as explanatory variables. A detailed description of controls is provided earlier and more information are provided in Table 4.

Corruption and financial or economic development studies have been affected by heterogeneity bias and require to control for the time-specific effects inherent among cross-sectional and time-series units. Failure to detect and control such effects could result in inconsistent parameter estimates. One of the solutions is to use either fixed or random effect panel regression. Following Bitterhout and Simo-Kengne [10], we apply the Hausman test to determine between the two types of panel estimators for the current study (Table 5).

Unlike past studies, we take several steps to control from endogeneity issues evident in our empirical model to ensure limited bias in our study findings. Endogeneity issues could affect the empirical model in three different ways. First, we have considered the problem of simultaneity which is also referred to as reverse causality in the current corruption and credit risk relationship. Bitterhout and Simo-Kengne [10] confirm the existence of reverse causality in corruption studies due to the presence of random shocks that could lead the financial development to affect corruption.

Omitted variable bias is the second and a common source of endogeneity in panel data models [35]. Other variables could be used to explain credit risk and corruption. While non-performing loan remains one of the most common measures of credit risk in past studies $[11,49]$, we also find new measures of credit risks have emerged in recent studies. For example, Hassan et al. [29] measure credit risk by dividing the loan change off and loan recoveries by last year allowance for non-performing loans. Similarly, bribery has been introduced as a measure of corruption by Nur-tegin and Jakee [40]. However, in an attempt to provide global evidence on the causal nexus between corruption and credit risk, we relied primarily on the data available in the World Bank database. Therefore, our model may not be able to measure credit risk and corruption with available proxies that have been adopted by researchers in past studies.

The final issue that could lead to an endogeneity bias is measurement error. The most common measurement errors occur due to the use of survey data [10]. In our study, we use the corruption perception score (CPI) score 
Table 4 Descriptive statistics

\begin{tabular}{|c|c|c|c|c|c|c|c|}
\hline Variables & Description & Source & Reference & Mean & SD & Max & Min \\
\hline Credit Risk & $\begin{array}{l}\text { Bank non-performing loans to total } \\
\text { gross loans }\end{array}$ & World Bank Database & Damanhur et al. [19] & 2.40 & 5.30 & 59.76 & 0.00 \\
\hline Corruption & $\begin{array}{l}\text { Corruption perception index (CPI) is } \\
\text { used as a measure of a country's } \\
\text { corruption level }\end{array}$ & Transparency International & Bougatef [15] & 6.36 & 2.44 & 10.00 & 0.00 \\
\hline Capitalization & $\begin{array}{l}\text { Bank capital to assets measures the } \\
\text { ratio of bank capital and reserves } \\
\text { to the total asset }\end{array}$ & World Bank Database & Bougatef [15] & 4.08 & 5.58 & 30.71 & 0.00 \\
\hline Credit Disclosure Index & $\begin{array}{l}\text { The index varies from } 0 \text { to } 8 \text {. The } \\
\text { higher the value, the more credit- } \\
\text { related information is available } \\
\text { and reliable }\end{array}$ & World Bank Database & Ben Saada [9] & 1.26 & 2.54 & 8.00 & 0.00 \\
\hline GDP Growth & $\begin{array}{l}\text { Annual growth of the real gross } \\
\text { domestic product }\end{array}$ & World Bank Database & Damanhur et al. [19] & 3.95 & 6.02 & 123.14 & -62.08 \\
\hline Inflation & $\begin{array}{l}\text { Consumer price index reflects the } \\
\text { annual percentage change in the } \\
\text { cost to the average consumer of } \\
\text { acquiring a basket of goods and } \\
\text { services }\end{array}$ & IMF Database & Damanhur et al. [19] & 4.40 & 5.16 & 48.70 & -8.97 \\
\hline Public Debt & $\begin{array}{l}\text { Debt is the entire stock of direct } \\
\text { government fixed-term contrac- } \\
\text { tual obligations to other outstand- } \\
\text { ing on a particular date }\end{array}$ & World Bank Database & Umar and Sun [48] & 2.36 & 4.97 & 59.76 & 0.00 \\
\hline Remittance & $\begin{array}{l}\text { Personal remittances comprise per- } \\
\text { sonal transfers and compensations } \\
\text { of employees }\end{array}$ & World Bank Database & Kumar et al. [34] & -0.05 & 0.96 & 1.94 & -2.81 \\
\hline Trade Openness & $\begin{array}{l}\text { The sum of total exports of imports } \\
\text { of goods and services as a share } \\
\text { of GDP }\end{array}$ & World Bank Database & Dreher and Siemers [24] & 6.19 & 24.36 & 174.16 & 0.00 \\
\hline Unemployment & $\begin{array}{l}\text { The share of the labour force that is } \\
\text { without work but available for and } \\
\text { seeking employment }\end{array}$ & World Bank Database & Kumar et al. [34] & 7.71 & 6.30 & 38.04 & 0.00 \\
\hline
\end{tabular}

provided by the Transparency International (TI) which is deemed to be biased by the level of economic growth, religious beliefs and democratic institutions [22]. Following Umar and Sun [48], we propose the use of Generalized Method of Moments (GMM) estimators to control for the endogeneity evident in the current study and capture the effect of NPLs of the previous period on current values. More specifically, the GMM model is using equation two:

\section{Results and discussion}

Table 4 provides the descriptive statistics of the variables used in this study. We report that on average $2.40 \%$ loans go bad every year with a standard deviation of 5.30. The maximum value for NPL is 59.76, while the lowest value of 0 is also found in the sample. Average corruption score is 6.36 with a standard deviation of 2.44. Our sample consists of countries in the two polar of the corruption index, i.e. very clean (0) and highly corrupt (10). Mean score of

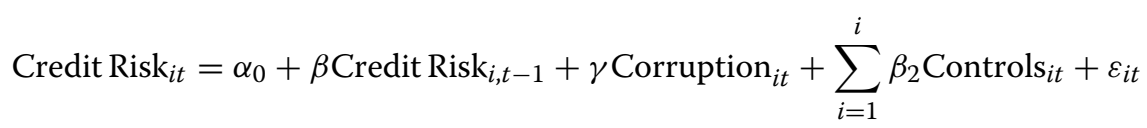

Here, Credit Risk ${ }_{i t}$ is measured using NPL to total gross loan ratio of bank $i$ in time $t$. We also introduce a lagged dependent variable Credit Risk ${ }_{i, t-1}$ which is is the lagged value of the NPL ratio; Controls $i t$ represents the vector of macroeconomic variables; Corruption ${ }_{i t}$ represents the explanatory variable and $\varepsilon_{i t}$ represents the error term. bank capital and reserve to the asset is 4.80 with a standard deviation of 5.58. Capital disclosure score is very poor with a mean score of 1.26. The index score ranges from 0 to 8. Gross Domestic Product (GDP) growth is promising with a mean score of 3.95 and a standard deviation of 6.02. Mean score of inflation, public debt, remittance, trade openness and unemployment is $4.40,2.36,-0.05$, 6.19 and 7.71 respectively. 


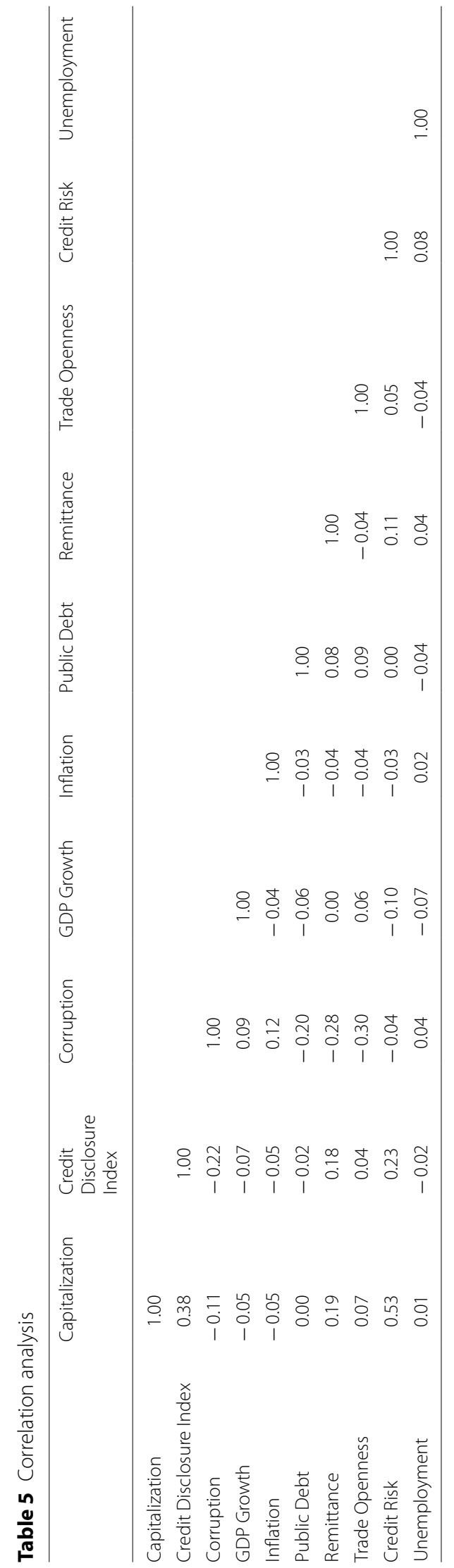


We perform panel least square regressions to determine the impact of corruption on credit risk. Credit risk of the banking sector is measured by the ratio of nonperforming loans to total gross loans (NPL). Several macroeconomic factors are included in the regression model (see Eq. 1). Bank specific variables are ignored in the economic model due to the global level of data used in this study. The most important findings of this study are that corruption has a positive association with the level of NPL. As can be seen in Table 6, the coefficient of corruption is positive and statistically significant at $1 \%$ level. Similar results are reported by Bougatef [15] on a sample of 22 emerging market economies over the period of 2008-2012. Therefore, the current study provides validity and generalizability of past findings with a sample of 178 countries over a period of 2000 to 2017. Moreover, we have performed GMM regression to verify the impact of lagged values of NPL based on the proposition of Umar and Sun [48]. Table 6 represents the results obtained by using the one-step GMM estimation for the entire sample. Results indicate that an increase in previous years' NPL results in a surge of NPL in the current year. Such

Table 6 Regression scores

\begin{tabular}{|c|c|c|c|c|}
\hline \multirow[t]{2}{*}{ Variables } & \multicolumn{2}{|l|}{ Panel OLS } & \multicolumn{2}{|l|}{ GMM } \\
\hline & Coefficient & t-statistics & Coefficient & t-statistics \\
\hline Corruption & 0.103 & $2.778(* * *)$ & 0.016 & 0.462 \\
\hline$N P L_{t-1}$ & - & - & 0.843 & $74.461(* * *)$ \\
\hline Capitalization & 0.497 & $31.146(* * *)$ & 0.132 & $12.114(* * *)$ \\
\hline $\begin{array}{l}\text { Credit Disclosure } \\
\text { Index }\end{array}$ & 0.079 & $2.361(* *)$ & -0.078 & $\left.-3.787{ }^{(* *}\right)$ \\
\hline GDP Growth & -0.068 & $-4.726(* * *)$ & -0.043 & $-4.827(* * *)$ \\
\hline Inflation & -0.004 & -0.880 & -0.001 & -0.171 \\
\hline Public Debt & -0.001 & -0.216 & -0.001 & -0.370 \\
\hline Remittance & 0.015 & 1.213 & -0.003 & -0.004 \\
\hline Trade Openness & 0.004 & $2.511(* *)$ & 0.001 & 0.628 \\
\hline Unemployment & 0.061 & $4.608(* * *)$ & 0.012 & 1.523 \\
\hline Constant & 0.095 & 0.340 & 0.126 & 0.462 \\
\hline Adjusted $r$-square & 0.289 & & 0.746 & \\
\hline F-value & $145.71(* * *)$ & & $3013 \wedge(* * *)$ & \\
\hline Observations & 3200 & & 2844 & \\
\hline Hausamn & $58.05\left(^{(* *)}\right.$ & & - & \\
\hline
\end{tabular}

We have performed both fixed and random effect regression based on the model: $\mathrm{NPL}_{i t}=\alpha_{i}+\beta_{1}$ Corruption $_{i t}+\sum_{i=1}^{i} \beta_{2}$ Controls $_{i t}+\varepsilon_{i t}$. We have also tried to capture the lag impact of NPL using the GMM model: $Y_{i t}=\alpha+\beta Y_{i, t-1}+\gamma$ Corruption $_{i t}+\sum_{k=1}^{k} \delta_{k}$ Corruption $_{t}^{k}+\varepsilon_{i t}$. Here, NPL is the dependent variable and is measured by the ratio of non-performing loans to total gross loans. A detailed description of the measurement variable and control variables are provided in Table 4. Hausman test score indicates that the fixed effect model is appropriate for the study. Therefore, we report fixed effect regression scores in Table 6.

$\wedge$ represent $j$-statistic score with the related $p$ value in the parenthesis. Asterisk ${ }^{* *}$ and ${ }^{* * *}$ represent significance level at 5 and $1 \%$ respectively. a result is in line with the findings of Ghosh [27]. In both panel OLS and GMM regression models, capitalization, credit disclosure index and GDP growth remains a significant predictor of NPL among the eight macroeconomic controls used in the economic model development. Both models are significant at $1 \%$ level with an adjusted r-square value of 28.9 and $74.6 \%$ for panel OLS and GMM model, respectively.

The nexus between corruption and development is not straightforward. Yakubu [50] argue that the spread of corruption varies across countries, resulting in an inconsistent impact of corruption on development between developing and developed countries. In Table 2, we group high and low corruption countries. We find that all developing countries fall within the group of high corruption countries while developed countries are grouped under low corruption countries. In high corruption countries, the weak form of institutions allows corruption to play a positive role in improving efficiency [39]. Therefore, we have performed a sub-sample analysis by dividing our main sample into the group of high and low corruption countries to further explore the corruption and credit risk nexus across developing and developed countries.

The median score of corruption is used as the basis to perform the sub-division of the sample. Low corruption counties include countries with a score below the median score (6.8) of the sample. Table 7 provides the sub-sample analysis. We find that the effect of corruption is positive for low corruption countries. Our findings contradict with the results of Bougatef [15]. However, our results indicate that increase of corruption in an already corrupt environment could have a detrimental impact on the credit risk. Our results support Ali et al. [4] that corruption allows defaulters to get access to risk credit through bribing lending authorities. Following the strong form hypothesis [39], we report a positive relationship between corruption and NPL for low corruption countries. We confirm the robustness of our findings by splitting the sample based on economic freedom. Chortareas et al. [18] find that a higher degree of financial freedom reduces the cost of financial institutions. We provide support for the "grease the wheel" hypothesis that corruption is beneficial with the presence of excessive regulatory pressure [23]. Such grease may allow borrowers to reduce costs resulting from redundant bureaucratic procedures, increasing bank lending.

We have performed two sets of robustness tests to check the robustness of our results. First, we perform a robust regression maintaining by introducing a new measurement of corruption. We have used control of corruption (CC) and data related to CC is obtained for the World Governance Indicators (WGI) published by the World Bank. The control of corruption measures 
Table 7 Sub-sample analysis

\begin{tabular}{|c|c|c|c|c|c|c|c|c|}
\hline \multirow[t]{2}{*}{ Variables } & \multicolumn{2}{|c|}{ High corruption countries } & \multicolumn{2}{|c|}{ Low corruption countries } & \multicolumn{2}{|c|}{ High economic freedom } & \multicolumn{2}{|c|}{ Low economic freedom } \\
\hline & Coefficient & t-statistics & Coefficient & t-statistics & Coefficient & t-statistics & Coefficient & t-statistics \\
\hline Corruption & -0.257 & $-2.252\left(^{(* *)}\right.$ & 0.278 & $4.353(* * *)$ & 0.175 & $3.37\left(^{* *}\right)$ & -0.022 & -0.27 \\
\hline Capitalization & 0.553 & $24.885\left(^{* * *}\right)$ & 0.398 & $17.237(* * *)$ & 0.356 & $14.14\left(^{* * *}\right)$ & 0.582 & $27.94(* * *)$ \\
\hline Credit Disclosure Index & 0.064 & 0.942 & 0.119 & $3.052(* * *)$ & 0.138 & $3.23(* *)$ & 0.049 & 0.92 \\
\hline GDP Growth & -0.039 & $-2.383\left(^{* *}\right)$ & -0.180 & $-5.706(* * *)$ & -0.155 & $-4.72(* * *)$ & -0.045 & $-2.74(* *)$ \\
\hline Inflation & 0.000 & 0.046 & -0.053 & $-3.033(* * *)$ & -0.081 & $-2.78\left(^{* *}\right)$ & -0.001 & -0.29 \\
\hline Public Debt & -0.003 & -0.530 & 0.003 & 0.803 & 0.004 & 1.26 & -0.016 & $-2.83(* *)$ \\
\hline Remittance & -0.014 & -0.880 & 0.016 & 0.756 & 0.053 & $2.60(* *)$ & 0.002 & 0.11 \\
\hline Trade Openness & -0.001 & -0.367 & 0.008 & $4.512(* * *)$ & 0.007 & $4.12\left(^{(* * *)}\right.$ & 0.002 & 0.81 \\
\hline Unemployment & -0.015 & -0.779 & 0.122 & $6.698(* * *)$ & 0.109 & $4.85\left(^{(* * *)}\right.$ & 0.030 & $1.84(* *)$ \\
\hline Constant & 3.200 & $2.861\left(^{* * *}\right)$ & -1.843 & $-3.162\left({ }^{* * *}\right)$ & -1.987 & $-3.35\left(^{* *}\right)$ & 0.485 & 0.60 \\
\hline Adjusted $r$-square & 0.330 & & 0.282 & & 0.238 & & 0.347 & \\
\hline$F$-value & $86.183\left({ }^{(* *}\right)$ & & $\left.72.5633^{* * *}\right)$ & & $48.95\left(^{* * *}\right)$ & & $\left.108.588^{* * *}\right)$ & \\
\hline Observations & 1764 & & 1436 & & 1381 & & 1819 & \\
\hline VIF & 1.12 & & 1.16 & & 1.17 & & 1.11 & \\
\hline Hausman Test & $16.31\left(^{*}\right)$ & & $\left.139.74{ }^{(* *}\right)$ & & $82.966^{(* * *)}$ & & 11.63 & \\
\hline
\end{tabular}

Countries are divided into high and low corruption countries based on the median $\mathrm{Cl}$ scores of 6.8 . Countries with a corruption score above 6.8 are classified as high corruption country while countries with corruption score below the median are classified as low corruption country. We divide the sample into high and low economic freedom based on their median score derived from the Economic Freedom Index provided by the Heritage Foundation. Finally, we have performed a fixed effect regression based on the model described in Table 6 . Asterisk *** and *** represent significance level at 10,5 and $1 \%$ respectively

the perception of the extent to which public power is exercised for private gain. We perform the analysis for both the full sample and sub-samples. This indicator result ranges from -2.5 to 2.5 A negative value indicates the absence of control of corruption and vice versa. Table 8 provides the robustness test results with alternative corruption measurement. Our results indicate that the lack of control of corruption has a negative impact on the NPL ratio for the full sample. Contrary to the subsample analysis, we report a

Table 8 Robustness test (alternative corruption measurement)

\begin{tabular}{|c|c|c|c|c|c|c|}
\hline \multirow[t]{2}{*}{ Variables } & \multicolumn{2}{|l|}{ Full sample } & \multicolumn{2}{|c|}{ High corruption } & \multicolumn{2}{|c|}{ Low corruption } \\
\hline & Coefficient & t-stat & Coefficient & t-stat & Coefficient & t-stat \\
\hline Control of Corruption & -0.012 & $\left.-3.5511^{* * *}\right)$ & 0.007 & 0.770 & -0.015 & $0.004\left(^{* * *}\right)$ \\
\hline Capitalization & 0.494 & $30.992(* * *)$ & 0.562 & $25.596\left({ }^{* * *}\right)$ & 0.409 & $0.023\left(^{* * *}\right)$ \\
\hline Credit Disclosure Index & 0.076 & $2.281\left(^{* *}\right)$ & 0.072 & 1.056 & 0.118 & $0.039\left(^{(* *}\right)$ \\
\hline GDP Growth & -0.065 & $-4.541\left(^{* * *}\right)$ & -0.038 & -2.282 & -0.151 & $0.0311^{(* * *)}$ \\
\hline Inflation & -0.003 & -0.742 & 0.000 & $0.075\left(^{* *}\right)$ & -0.041 & $0.017\left(^{* *}\right)$ \\
\hline Public Debt & -0.001 & -0.428 & -0.006 & -0.884 & 0.001 & 0.003 \\
\hline Remittance & 0.010 & 0.854 & -0.002 & -0.155 & 0.011 & 0.021 \\
\hline Trade Openness & 0.004 & $2.486\left(^{* *}\right)$ & -0.001 & -0.334 & 0.007 & $\left.0.002^{(* * *}\right)$ \\
\hline Unemployment & 0.062 & $4.688\left(^{* * *}\right)$ & -0.016 & -0.806 & 0.137 & $0.018\left(^{(* *}\right)$ \\
\hline Constant & 0.027 & 0.099 & 0.791 & 2.208 & -0.297 & 0.532 \\
\hline Adjusted r-square & 0.290 & & 0.328 & & 0.281 & \\
\hline F-value & $146.548\left({ }^{* * *}\right)$ & & $85.438(* * *)$ & & $72.229(* * *)$ & \\
\hline Observations & 3200 & & 1764 & & 1437 & \\
\hline
\end{tabular}

We have performed panel least square regression based on the model: NPL $i t=\alpha_{i}+\beta_{1}$ Corruption $_{i t}+\sum_{i=1}^{i} \beta_{2}$ Controls $_{i t}+\varepsilon_{i t}$. However, the measure of corruption is changed in this regression analysis. We have used control of corruption scores from the World Governance Indicator, published by World Bank in this model. The control of corruption scores ranges from approximately -2.5 to 2.5 . A negative score indicates higher utilization of public power for private gain and vice versa. Hausman test score indicates that the fixed effect model is appropriate for the study. Therefore, we report fixed effect regression scores in Table 8.

Asterisk ** and *** represent significance level at 5 and $1 \%$ respectively. 
positive (negative) association between control of corruption and NPL for high corruption (low corruption) countries. Therefore, we emphasize the importance of the control of corruption which can play an effective role in reducing the bad loan portfolio of the banking system.

In the second phase of the robustness test, we have made changes in the control variables. A new set of control is introduced in the model which include five measures of governance provided in the World Governance Indicators (WGI), published by the World Bank. While Beck et al. [8] find little evidence that supervisory agencies improve bank's corporate governance and reduce corruption in bank lending, we followed Ben Saada [9] who reports that governance practices affect credit risk and bank stability as well. Kamarudin et al. [32] utilized similar measures to study the efficiency of country governance on the revenue and efficiency of Islamic and conventional banks. Results reported in Table 9 prove the robustness of the relationship between corruption and nonperforming loans. For both models with an additional set of control variables, we conclude that corruption is negatively related to NPL suggesting that corruption adversely affects the loan portfolio of the banking sector. Therefore, we accept $\mathrm{H}_{1}$.

\section{Conclusion}

We explored the role of corruption on the loan quality of the banking sector. The primary rationale for such an investigation is twofold. First, corruption is a complex phenomenon and has been found to have mixed impact on institutional efficiency concerning the "Grease or sand the wheel" hypothesis. Second, the association between corruption and credit risk has hardly been studied. Therefore, we have tried to provide global evidence on the impact of corruption on NPL. Our findings reveal a robust relationship between corruption and NPL. We report a negative relationship between corruption and NPL which is in line with few studies conduct in this context. However, a subdivision of the full sample into high and low corruption countries provided interesting findings and revealed the complex nature of corruption. We found corruption to have a negative association with NPL for high corruption countries and the opposite for low corruption countries. Such results are in line with the "Grease the wheel" hypothesis and indicate that corruption provides opportunities to speed up a sluggish bureaucratic administrative administration, concluding that corruption may positively contribute to growth and development with the compromise of the consequences of a defective bureaucracy and bad policies.

Our results have several implications for public policy. Regulators in high corruption countries should

Table 9 Robustness test 2 (change of control variables)

\begin{tabular}{|c|c|c|c|c|}
\hline \multirow[t]{2}{*}{ Variables } & \multicolumn{2}{|l|}{ Model 1} & \multicolumn{2}{|l|}{ Model 2} \\
\hline & Coefficient & t-stat & Coefficient & $t$-stat \\
\hline Corruption & - & - & 0.017 & $3.459\left({ }^{* * *}\right)$ \\
\hline Control of Corruption & -1.388 & $-3.197(* * *)$ & - & - \\
\hline GDP Growth & -0.082 & $-4.925(* * *)$ & -0.075 & $-4.503(* * *)$ \\
\hline Unemployment & 0.060 & 3.941 & 0.064 & $4.191(* * *)$ \\
\hline Inflation & -0.009 & $-1.697(* * *)$ & -0.007 & -1.247 \\
\hline Government Effectiveness & 0.680 & $1.612(* * *)$ & -0.767 & $-3.939(* * *)$ \\
\hline Political Stability & 0.690 & $3.627\left(^{* * *}\right)$ & 0.743 & $3.837(* * *)$ \\
\hline Regulatory Quality & 1.255 & $3.415\left(^{* * *}\right)$ & 1.934 & $5.829\left({ }^{* * *}\right)$ \\
\hline Rule of Law & -0.940 & $-2.572(* * *)$ & -1.612 & $-4.885(* * *)$ \\
\hline Voice of Accountability & 0.096 & 1.251 & 0.027 & 0.338 \\
\hline Constant & 3.503 & $9.163(* * *)$ & 3.503 & 9.163 \\
\hline Adjusted $r$-square & 0.041 & & 0.042 & \\
\hline F-value & $16.265\left(^{(* *}\right)$ & & $16.473(* * *)$ & \\
\hline Observations & 3200 & & 3200 & \\
\hline
\end{tabular}

We have performed panel least square regression based on the model: NPL $L_{i t}=\alpha_{i}+\beta_{1}$ Corruption $_{i t}+\sum^{i} \beta_{2}$ Controls $_{i t}+\varepsilon_{i t}$. In model 1 , the measure of corruption is the CPI score obtained from Transparency International. In model 2, we used the control of corruption as an explanatory variable. In both models, three control variable is retained from the original model which include GDP growth, unemployment and inflation. In addition to these three control variables, five control variables are introduced from World Governance Indicators (WGI) published by the World Bank. Hausman test score indicates that the fixed effect model is appropriate for the study. Therefore, we report fixed effect regression scores in Table 9.

Asterisk ${ }^{* *}$ and ${ }^{* * *}$ represent significance level at 5 and $1 \%$ respectively. 
reconsider the cost and benefits of allowing corruption, in the form of bribery and tax evasion, to grease the economic development of the country and emphasize on developing effective governance mechanisms to ensure sustainable growth of financial institutions. In the case of low corruption countries, corruption plays an adverse role in NPL and highlights the importance governance structure that could ensure the sound operation of the banking sector and stimulate economic growth. Therefore, we propose that policymakers should focus on introducing reforms to enhance transparent reporting by enforcing mandatory audits. We recommend the adoption of voluntary disclosure standards, such as the Global Reporting Initiative (GRI) standards, to ensure proper disclosure of both financial and non-financial impact of corruption in the firm performance. Overall, this study recommends establishing effective mechanisms to fight against corruption with an inherent motivation toward ensuring effective credit screen mechanisms which has a wider implication toward the small and medium industry. Future research can be conducted on this issue to provide more insight into the impact of corruption on the growth of the SME sector from a global perspective.

\section{Abbreviations}

2SLS: Two-stage least squares; CC: Control of Corruption; Cl: Corruption Index; CPI: Corruption Perception Index; GDP: Gross Domestic Product; GMM: Generalized Methods of Moments; IMF: International Monetary Fund; NPL: Non-performing loans; OLS: Ordinary Least Squares; WGI: World Governance Indicators.

\section{Acknowledgements \\ All authors are acknowledged.}

\section{Authors' contributions}

Each author made substantial contributions to the conception, design and interpretation of data. $\mathrm{RH}$ conceived of the presented idea, developed the theory and performed the computations. MA contributed toward drafting the introduction, performed critical review of past literature to develop the hypothesis that is aligned with the idea and analytical findings of RH. All authors discussed the final results and contributed toward the development of the final manuscript. All authors have read and approved the final manuscript.

\section{Funding}

There is not funding to declare.

\section{Availability of data and materials}

All data used to reach the concluding will be made available for public use.

\section{Declarations}

\section{Competing interests}

There are no financial and non-financial competing interest to declare for this paper.

\section{Author details}

${ }^{1}$ School of Economics, Finance and Accounting, Coventry University, Priory St, CV1 5FB Coventry, Warwickshire, United Kigngdom. ${ }^{2}$ Wittenborg University of Applied Sciences, Spoorstraat 23, 7311 PE Apeldoorn, The Netherlands.
Received: 1 April 2020 Accepted: 29 March 2021

Published: 21 April 2021

\section{References}

1. Abuzayed B, Ammar MB, Molyneux P, Al-Fayoumi N (2019) Corruption, lending and bank performance. School of Business Administration Working Paper Series No. 3/11/2019

2. Akins B, Dou Y, Ng J (2017) Corruption in bank lending: the role of timely Ioan loss recognition. J Account Econ 63(2-3):454-478. https://doi.org/ 10.1016/j.jacceco.2016.08.003

3. Ali A, Daly K (2010) Macroeconomic determinants of credit risk: recent evidence from a cross country study. Int Rev Financ Anal 19(3):165-171

4. Ali MSB, Fhima F, Ridha N (2020) How does corruption undermine banking stability? A threshold nonlinear framework. J Behav Exp Financ 27:100365. https://doi.org/10.1016/j.jbef.2020.100365

5. Atkins, B., Dou, Y., \& Ng, J. T. Y. (2015). Corruption in bank lending: The role of timely loan loss provisioning. https://ink.library.smu.edu.sg/soa_resea $\mathrm{rch} / 1430$

6. Bahoo S (2020) Corruption in banks: a bibliometric review and agenda. Financ Res Lett 35:101499

7. Barth JR, Lin C, Lin P, Song FM (2009) Corruption in bank lending to firms: cross-country micro evidence on the beneficial role of competition and information sharing. J Financ Econ 91(3):361-388

8. BeckT, Demirguc-Kunt A, Levine R (2006) Bank supervision and corruption in lending. J Monet Econ 53(8):2131-2163

9. Ben Saada M (2018) The impact of control quality on the non-performing loans of Tunisian listed banks. Manag Audit J 33(1):2-15

10. Bitterhout S, Simo-Kengne BD (2020) The effect of corruption on economic growth in the BRICS countries. A panel data analysis. EDWRG Working Paper Series No. 03-2020. Johannesburg.

11. Boateng A, Liu Y, Brahma S (2019) Politically connected boards, ownership structure and credit risk: evidence from Chinese commercial banks. Res Int Bus Financ 47:162-173. https://doi.org/10.1016/j.ribaf.2018.07.008

12. Bolarinwa ST, Soetan F (2019) The effect of corruption on bank profitability. J Financ Crime 26(3):753-790. https://doi.org/10.1108/ JFC-09-2018-0102

13. Boudriga A, Taktak N, Jellouli S (2009) Bank specific, business and institutional environment determinants of nonperforming loans: evidence from MENA countries (No. 547). Economic research forum 16th annual conference, Cairo

14. Bougatef K (2015) The impact of corruption on the soundness of Islamic banks. Borsa Istanbul Rev 15(4):283-295

15. Bougatef K (2016) How corruption affects loan portfolio quality in emerging markets? J Financ Crime 23(4):769-785

16. Bougatef K (2017) Determinants of bank profitability in Tunisia: does corruption matter? J Money Laundering Control 20(1):70-78

17. Brown NC, Smith JD, White RM, Zutter CJ (2021) Political corruption and firm value in the US: Do rents and monitoring matter? J Bus Ethics 168:335-351

18. Chortareas GE, Girardone C, Ventouri A (2013) Financial freedom and bank efficiency: evidence from the European Union. J Bank Finance 37(4):1223-1231

19. Damanhur AW, Syamni G, Habibie M (2018) What is the determinant of non-performing financing in Branch Sharia Regional Bank in Indonesia? In: Proceedings of MICoMS 2017, pp 265-271

20. Dass N, Nanda V, Xiao SC (2016) Public corruption in the United States: Implications for local firms. Rev Corp Finance Stud 5(1):102-138

21. Dimitrios A, Helen L, Mike T (2016) Determinants of non-performing loans: evidence from Euro-area countries. Financ Res Lett 18:116-119

22. Donchev D, Ujhelyi G (2014) What do corruption indices measure? Econ Politics 26(2):309-339

23. Dreher A, Gassebner M (2013) Greasing the wheels? The impact of regulations and corruption on firm entry. Public Choice 155(3-4):413-432

24. Dreher A, Siemers LH (2009) The nexus between corruption and capital account restrictions. Public Choice 140(1-2):245-265

25. Fan JP, Rui OM, Zhao M (2008) Public governance and corporate finance: evidence from corruption cases. J Comp Econ 36(3):343-364 
26. Geletta WN (2012) Determinants of non-performing loans: the case of Ethiopian Banks. The University of South Africa. https://core.ac.uk/down oad/pdf/43168979.pdf

27. Ghosh A (2015) Banking-industry specific and regional economic determinants of non-performing loans: evidence from US states. J Financ Stab 20:93-104

28. Ghosh S (2017) Corporate governance reforms and bank performance: evidence from the Middle East and North Africa. Corp Gov Int J Bus Soc 17(5):822-844

29. Hassan MK, Khan A, Paltrinieri A (2019) Liquidity risk, credit risk and stability in Islamic and conventional banks. Res Int Bus Financ 48:17-31. https://doi.org/10.1016/j.ribaf.2018.10.006

30. Huang CJ (2016) Is corruption bad for economic growth? Evidence from Asia-Pacific countries. N Am J Econ Finance 35:247-256

31. Islam MS, Nishiyama SI (2019) Non-performing loans of commercial banks in South Asian Countries: adverse selection and moral hazard issues. Asian Econ Financ Rev 9(9):1091

32. Kamarudin F, Sufian F, Nassir AM (2016) Does country governance foster revenue efficiency of Islamic and conventional banks in GCC countries? EuroMed J Bus 11(2):181-211

33. Khalil F, Lawarrée J, Yun S (2010) Bribery versus extortion: allowing the lesser of two evils. Rand J Econ 41(1):179-198

34. Kumar RR, Stauvermann PJ, Patel A, Prasad SS (2018) Determinants of non-performing loans in the banking sector in small developing island states: a study of Fiji. Account Res J 31(2):192-213

35. Lahouel BB, Gaies B, Zaied YB, Jahmane A (2019) Accounting for endogeneity and the dynamics of corporate social-corporate financial performance relationship. J Clean Prod 230:352-364. https://doi.org/10. 1016/j.jclepro.2019.04.377

36. Mauro P (1995) Corruption and growth. Quart J Econ 110:681-712

37. Mauro P, Driscoll DD (1997) Why worry about corruption?, vol 6. International Monetary Fund, Washington, DC, pp 1-19

38. Mauro T, Elias P, Cullander C, Bench G, Sidderas-Haddad E, Feingold K (1998) Acute barrier perturbation abolishes the Ca2+ and K+ gradientsin murine epidermis: quantitative measurement using PIXE. Journal of Investigative Dermatology 111(6):1198-1201

39. Méon P-G, Weill L (2010) Is corruption an efficient grease? World Dev 38(3):244-259

40. Nur-tegin K, Jakee K (2020) Does corruption grease or sand the wheels of development? New results based on disaggregated data. Q Rev Econ Finance 75:19-30. https://doi.org/10.1016/j.qref.2019.02.001
41. Ozili PK (2019) Bank income smoothing, institutions and corruption. Res Int Bus Financ 49:82-99

42. Park J (2012) Corruption, soundness of the banking sector, and economic growth: a cross-country study. J Int Money Financ 31(5):907-929

43. Richard E (2011) Factors that cause non-performing loans in commercial banks in Tanzania and strategies to resolve them. J Manag Policy Pract 12(7):16-23

44. Song CQ, Chang CP, Gong Q (2020) Economic growth, corruption, and financial development: global evidence. Econ Model. https://doi.org/10. 1016/j.econmod.2020.02.022

45. Tabish SZS, Jha KN (2012) The impact of anti-corruption strategies on corruption free performance in public construction projects. Constr Manag Econ 30(1):21-35

46. Transparency International (2015a) Corruption perception index 2015. https://Www.Transparency.Org/En/Cpi/2015/Index/. Retrieved 15 March2019, from https://www.transparency.org/en/cpi/2015/index/

47. Uddin A, Chowdhury MAF, Sajib SD, Masih M (2020) Revisiting the impact of institutional quality on post-GFC bank risk-taking: Evidence from emerging countries. Emerg Mark Rev 42:100659

48. Umar M, Sun G (2018) Determinants of non-performing loans in Chinese banks. J Asia Bus Stud 12(3):273-289

49. Warninda TD, Ekaputra IA, Rokhim R (2019) Do Mudarabah and Musharakah financing impact Islamic Bank credit risk differently? Res Int Bus Financ 49:166-175

50. Yakubu IN (2019) Does corruption grease or sand the wheels of bank profitability in Ghana? Cogent Economics \& Finance 7(1):1701909

51. Zha Y, Power D, Tantisantiwong N (2020) The cross-country transmission of credit risk between sovereigns and firms in Asia. Q Rev Econ Finance. https://doi.org/10.1016/j.qref.2020.04.005

52. Zhang Z-Y, Wu J, Liu Q-F (2008) Impacts of capital adequacy regulation on risk-taking behaviours of banking. Syst Eng Theory Pract 28(8):183-189

53. Šumah Š (2018) Corruption, causes and consequences. In: Trade and Global Market. University of Applied Sciences FH Joanneum. https://doi. org/10.5772/intechopen.70966

\section{Publisher's Note}

Springer Nature remains neutral with regard to jurisdictional claims in published maps and institutional affiliations.

\section{Submit your manuscript to a SpringerOpen ${ }^{\circ}$ journal and benefit from:}

- Convenient online submission

- Rigorous peer review

- Open access: articles freely available online

- High visibility within the field

- Retaining the copyright to your article

Submit your next manuscript at springeropen.com 